\title{
Metabolic and Renal Clearance Rates of Purified Human Chorionic Gonadotropin
}

\author{
Robert E. Wehmann and Bruce C. Nisula, Developmental Endocrinology Branch, \\ National Institute of Child Health and Human Development, \\ National Institutes of Health, Bethesda, Maryland 20205; \\ Gerontology Research Center, National Institute on Aging, \\ Baltimore City Hospitals, Baltimore, Maryland 21224
}

\begin{abstract}
A B S T RACT The metabolic clearance rate (MCR) and renal clearance rate (RCR) of human chorionic gonadotropin (hCG) were measured in healthy young men and women using techniques of continuous intravenous infusion and rapid intravenous injection of unlabeled, highly purified hCG. Seven subjects received $4 \mathrm{~d}$ of infusion at a rate of $0.2 \mu \mathrm{g} / \mathrm{min}$, followed by an additional $4 \mathrm{~d}$ of infusion at $0.8 \mu \mathrm{g} / \mathrm{min}$. Mean serum levels of hCG established at these rates of infusion were $61.1 \pm 3.3$ and $237 \pm 16 \mathrm{ng} / \mathrm{ml}$, respectively (mean \pm SEM). The MCR determined at the low infusion rate was not significantly different from that determined at the higher infusion rate $(1.83 \pm 0.09$ vs. $1.95 \pm 0.14$ $\mathrm{ml} / \mathrm{min}$ per $\mathrm{m}^{2}$ ). The mean MCR for all subjects was $1.88 \pm 0.08 \mathrm{ml} / \mathrm{min}$ per $\mathrm{m}^{2}$. The MCR was not significantly different between men and women (2.04 \pm 0.13 vs. $1.76 \pm 0.07 \mathrm{ml} / \mathrm{min}$ per $\left.\mathrm{m}^{2}\right)$. The RCR also did not vary between low and high infusion rates $(0.40 \pm 0.03$ vs. $0.40 \pm 0.04 \mathrm{ml} / \mathrm{min}$ per $\mathrm{m}^{2}$ ). The mean RCR for all subjects was $0.40 \pm 0.02 \mathrm{ml} / \mathrm{min}$ per $\mathrm{m}^{2}$. There was no difference in RCR between men and women $(0.42$ \pm 0.05 vs. $0.39 \pm 0.03 \mathrm{ml} / \mathrm{min}$ per $\left.\mathrm{m}^{2}\right)$. Six subjects were given $1.0 \mathrm{mg}$ of highly purified hCG by rapid intravenous injection. Initial serum levels of hCG were 300 $400 \mathrm{ng} / \mathrm{ml}$, and the subsequent disappearance curve was multiexponential over 8-10 d. The disappearance curve of hCG in each subject was fitted to a biexponential equation. The rapid component $t_{1 / 2}$ was $5.97 \pm 0.63 \mathrm{~h}$ and the slow component $t_{1 / 2}$ was $35.6 \pm 8.0 \mathrm{~h}$. We conclude that the MCR of purified hCG in man is about $2 \mathrm{ml} / \mathrm{min}$ per $\mathrm{m}^{2}$ and the RCR is $0.4 \mathrm{ml} / \mathrm{min}$ per $\mathrm{m}^{2}$; these parameters are concentration independent and do not
\end{abstract}

Address reprint requests to Dr. Bruce C. Nisula, Building 10, Room 10-B-09, National Institutes of Health, Bethesda, Md. 20205.

Received for publication 23 October 1980 and in revised form 18 February 1981. differ significantly between healthy young men and women.

\section{INTRODUCTION}

The metabolism of human chorionic gonadotropin (hCG) ${ }^{1}$ has been the subject of a number of reports during the past $40 \mathrm{yr}(1-10)$. It has been established that the hCG molecule has a plasma metabolic clearance rate (MCR) that is quite slow relative to the MCR of the pituitary glycoprotein hormones (1-5), and that urinary excretion accounts for some, but not all, of the metabolic disposal of hCG $(1,2,5-10)$. Techniques for quantitation of hCG metabolism have varied, and each has its limitations. For example, the disappearance of endogenous hCG after delivery of the placenta has been determined by radioimmunoassay $(1,4)$; however, a number of hCG-related molecules circulate during pregnancy and gestational trophoblastic disease (11-15), and these species may have differing rates of disappearance. Furthermore, the persistence of hCG secretion by some residual trophoblastic tissue may complicate the kinetic analysis. Some investigators have injected crude commercial preparations of hCG and have analyzed the kinetics of disappearance of hCG biological or immunological activity from blood $(2,3,5)$. However, crude preparations of hCG contain immunologically active, but biologically inactive hCG-related peptides (5). Accordingly, we have used highly purified hCG to study the metabolism of hCG. Our experimental approach was to use both a single injection technique, as employed by other investigators, and a continuous intravenous infusion, the latter

\footnotetext{
${ }^{1}$ Abbreviations used in this paper: Con A-Sepharose, concanavalin A covalently bound to Sepharose 4B; hCG, human chorionic gonadotropin; hLH, human luteinizing hormone; MCR, metabolic clearance rate; PBS, phosphatebuffered saline; RCR, renal clearance rate.
} 
technique not having been applied to the measurement of hCG metabolic parameters heretofore.

\section{METHODS}

\section{Materials}

We obtained the highly purified hCG CR121 preparation from the Center for Population Research of the National Institute of Child Health and Human Development. It was prepared by Dr. Robert Canfield and Dr. Steven Birken using the same method as used for hCG CR119 (16). We have found these two hCG preparations to be indistinguishable by a variety of criteria, including potency in bioassay, radioimmunoassay, and LH-CG radioreceptor assay systems, and gel filtration pattern on Sephadex G-100. The biological potency of hCG CR121 is $14,000 \mathrm{IU} / \mathrm{mg}(9,900-17,300 \mathrm{IU} / \mathrm{mg}, 95 \%$ confidence limits) in terms of the Second International Standard of hCG (ventral prostate weight bioassay). The hCG CR121 preparation was made suitable for human administration by millipore filtration. The antisera to hCG $\beta$ (SB6) and to hCG $\alpha$ (SA7) have been characterized previously (13, 17). Antiserum generated against the carboxy-terminal peptide of hCG $\beta$ was also employed (18). Concanavalin A covalently bound to Sepharose 4B (Con A-Sepharose) was purchased from Pharmacia Fine Chemicals, Piscataway, N. J. $\alpha$-MethylD-mannoside was purchased from Sigma Chemical Co., St. Louis, Mo.

\section{Subjects}

Six male and seven female National Institutes of Health Clinical Center normal volunteers, aged 18-22 yr, participated in the study after giving informed consent. Injections or infusions of hCG were given to the women late in the luteal phase or during menstruation to avoid the ovulatory surge of luteinizing hormone.

\section{Base-line samples}

Three base-line 24-h urine specimens and three base-line blood samples $(10 \mathrm{ml})$ were obtained from each subject before the administration of hCG.

\section{Continuous infusion technique}

Seven subjects (three men and four women) were given purified hCG by continuous intravenous infusion. The subjects were allowed to pursue their normal diets and activities within the constraints imposed by the intravenous infusion apparatus (IMED portable intravenous flow pump). At $0800 \mathrm{~h}$ of the lst d, a loading dose of $0.2 \mathrm{mg}$ of purified hCG was injected intravenously, and continuous infusion was begun of a solution of $500 \mathrm{ml} 0.9 \% \mathrm{NaCl}$ containing $0.15 \mathrm{mg} \mathrm{hCG}$ and 2 $\mathrm{ml}$ of $25 \%$ human serum albumin. The infusion was maintained at a flow rate of $40 \mathrm{ml} / \mathrm{h}$. The intravenous solutions were prepared fresh and changed every $12 \mathrm{~h}$. After $4 \mathrm{~d}(96 \mathrm{~h})$, an additional $0.6 \mathrm{mg}$ of purified hCG was injected intravenously, and the concentration of hCG in the infusate was increased to $0.6 \mathrm{mg} / 500 \mathrm{ml}$. The actual flow rate was determined on several occasions by measuring the weight of fluid delivered during $12 \mathrm{~h}$ by the pump into a tared collection flask. The mean flow rate determined in this way was $38.9 \pm 0.7$ $\mathrm{ml} / \mathrm{h}( \pm \mathrm{SD})$. An aliquot of the infusate given to each subject was stored at $-20^{\circ} \mathrm{C}$ until assayed for hCG; thus, it was possible to measure the rate of infusion of hCG during each 12$h$ period. Blood samples $(10 \mathrm{ml})$ were drawn from the contralateral arm every $12 \mathrm{~h}$, just before the intravenous solution was changed. 24 -h urine specimens were obtained each day during the 8-d infusion period. Because of technical difficulties with maintaining the intravenous infusion, data were not obtained in two subjects at the higher rate of infusion.

\section{Single injection technique}

At $0800 \mathrm{~h}$, after overnight fasting, six subjects (three men and three women) were given a rapid intravenous injection of $1.0 \mathrm{mg}$ of purified hCG in $5 \mathrm{ml}$ of $0.9 \% \mathrm{NaCl}$ into a right antecubital vein. Blood samples $(10 \mathrm{ml})$ were obtained at various times during the next $16 \mathrm{~h}$ via an intravenous line in a left forearm vein; the line was kept open by an infusion of $0.9 \% \mathrm{NaCl}$ at $40 \mathrm{ml} / \mathrm{h}$. During the day of injection, the subjects were allowed a clear liquid lunch. After $8 \mathrm{~h}$ at bed rest, normal diet and activities were resumed. Additional blood samples $(10 \mathrm{ml})$ were taken daily for the next 8-12 d, and $24 \mathrm{~h}$ urine specimens were collected for each of $12-15 \mathrm{~d}$ after injection. Creatinine concentration was measured in each urine specimen to ensure that adequate collections had been obtained.

\section{Processing of samples}

All samples of blood were allowed to clot and were centrifuged at $1500 \mathrm{~g}$ for $15 \mathrm{~min}$ to separate the serum. Urine was kept refrigerated until the end of the collection period. Aliquots of serum, urine, and infusate were stored at $-20^{\circ} \mathrm{C}$ for subsequent analysis.

\section{Radioimmunoassays}

The hCG $\beta$ determinant radioimmunoassay employed antiserum generated against the hCG $\beta$ subunit (SB6) (17); hCG CR119 iodinated with ${ }^{125}$ I by the chloramine T method (19) was used as the radioligand, and hCG CR 121 was the reference preparation.

The hCG $\alpha$ determinant radioimmunoassay used antiserum against the hCG $\alpha$ subunit (SA7) (13); hCG $\alpha$ (CR119), iodinated with ${ }^{125} \mathrm{I}$ by the chloramine $\mathrm{T}$ method (19), was used as the radioligand, and hCG $\alpha$ (CR119) was the reference preparation.

The hCG $\beta$ carboxy-terminal peptide determinant radioimmunoassay used an antiserum to the hCG $\beta$ carboxyterminal peptide (18) in a system which used labeled hCG CR119 as the radioligand and hCG CR121 as the reference preparation.

\section{Serum and infusate samples}

To eliminate interassay variability, serum and infusate samples from individual subjects were run in the same assay. Aliquots of infusate and sera derived from the continuous infusion technique were diluted in radioimmunoassay buffer, and potency estimates were made using the reference preparation diluted in the same buffer. Each unknown sample was run in the assay at three different dilutions, such that the resulting displacement of radioligand was between 20 and $80 \%$ in at least two of the three dilutions. Dose interpolations for the unknown samples were made using parallel line bioassay statistical methods (20).

For subjects given hCG by rapid injection, sera and standards were diluted in normal male (blank) serum to a volume of $200 \mu \mathrm{l}$. 


\section{Urine samples}

To minimize nonspecific effects of urine on the radioimmunoassays, Con A-Sepharose was used to extract hCG from the urine specimens as described previously $(21,22)$. Briefly, amounts of urine up to $1.5 \mathrm{ml}$ were mixed with $300 \mu \mathrm{l}$ of a slurry of Con A-Sepharose (1:1, vol/vol in phosphate-buffered saline [PBS, $\left.0.15 \mathrm{M} \mathrm{NaCl}, 0.01 \mathrm{M} \mathrm{PO}_{4}, \mathrm{pH} 7.4\right]$ ) and mixed by vortex three to four times during $45 \mathrm{~min}$ at room temperature. Recovery of the purified hCG by this procedure was $92 \pm 5 \%$ and was accounted for in calculating the results. $\alpha$-Methyl-D-mannoside ( $0.25 \mathrm{M}$ final concentration) was added to the routine radioimmunoassay buffer to inhibit adsorption of labeled hCG to the Con A-Sepharose gel.

\section{Gel filtration}

Samples of urine and infusate $(1.0 \mathrm{ml})$, with $5-10,000 \mathrm{cpm}$ of ${ }^{125} \mathrm{I}-\mathrm{hCG} \alpha$ added as a column marker, were applied to a column of Sephadex G-100 $(69.5 \times 1.6 \mathrm{~cm})$ and eluted with PBS by upward filtration at a flow rate of $25 \mathrm{ml} / \mathrm{h}$. Fractions of $2.3 \mathrm{ml}$ were collected and an aliquot of each fraction was counted for ${ }^{125} \mathrm{I}$.

Samples of serum $(2.0 \mathrm{ml})$, with $5-10,000 \mathrm{cpm}$ of ${ }^{125} \mathrm{I}-\mathrm{hCG} \alpha$ added as a column marker, were applied to a column of Sephadex G-100 $(83.5 \times 2.6 \mathrm{~cm})$, and eluted with PBS by upward filtration at $25 \mathrm{ml} / \mathrm{h}$. Fractions of $2.3 \mathrm{ml}$ were collected and aliquots counted for ${ }^{125} \mathrm{I}$. The fractions obtained from these columns were assayed in the various radioimmunoassays either directly or after Con A-Sepharose extraction. The immunoreactive moieties which eluted from the column contained sufficient carbohydrate for adsorption to Con A-Sepharose.

\section{Analysis of data}

Continuous infusion. The steady-state serum concentration of hCG during the infusion was used to calculate the MCR by the formula, MCR = IR/C, where IR is the infusion rate $(\mathrm{ng} / \mathrm{min})$ and $\mathrm{C}$ is the steady-state serum concentration (ng/ml). The renal clearance rate (RCR) was calculated according to the formula, $R C R=U / C$, where $U$ is the quantity of hCG excreted in the urine during the period, and $C$ is the steady-state serum concentration.

Single injection. The disappearance of hCG from serum was curvilinear on a semilog plot, and for purposes of calculating curve parameters and estimating clearance rates from the data, a curve-fitting computer program (23) was used to fit the data to an equation of the form, $\mathrm{C}=\mathrm{Ae}^{-\alpha t}+\mathrm{Be}^{-\beta t}$, where $C$ is the serum concentration, $t$ is the time, $A$ and $\alpha$ are the rapid component parameters, and $B$ and $\beta$ are the slow component parameters. The MCR was calculated as the total dose administered divided by the area under the disappearance curve (integral with respect to time, from 0 to infinity). The formula used was $M C R=\operatorname{Dose} /(A / \alpha+B / \beta)$. The apparent initial volume of distribution $\left(V_{d}\right)$ was calculated as: $V_{d}=\operatorname{Dose} /(A+B)$. The rapid and slow component halflives were calculated as $(\ln 2) / \alpha$ and $(\ln 2) / \beta$, respectively. The RCR was calculated as the amount of hCG excreted in the urine during the first $72 \mathrm{~h}$ after injection divided by the integral of the disappearance curve during this same time period. The formula used was $\mathrm{RCR}=\mathrm{U} /\left(\int_{0}^{3} \mathrm{Cdt}\right)$, where $\mathrm{U}$ is the quantity of hCG excreted in the urine during the $72 \mathrm{~h}$, $C$ is the serum concentration, and $t$ is the time.

Body surface area was estimated from height and weight by the formula of Du Bois and Du Bois (24).
Statistical analysis of the radioimmunoassays was performed as described by Rodbard (20). For comparison of means, we used Student's $t$ test (25).

\section{RESULTS}

MCR of hCG determined by continuous infusion technique. Base-line serum levels of hCG were at or below the limits of detection of the radioimmunoassay $(\leq 1.0 \mathrm{ng} / \mathrm{ml})$ in all subjects. An initial rapid intravenous injection of hCG was given to raise rapidly the blood level to near the desired concentration. Fig. 1 shows the levels of hCG which were achieved in the serum of the subjects during the infusion of hCG at $0.2 \mu \mathrm{g} / \mathrm{min}$ and $0.8 \mu \mathrm{g} / \mathrm{min}$. Mean serum hCG levels on the $3 \mathrm{rd} \mathrm{d}$ of continuous infusion were not significantly different from those on the 4 th $\mathrm{d}$ (paired $t$ test, 0.05 level). For each subject, the serum hCG levels during the 3rd and 4th $\mathrm{d}$ were averaged, and the average value was used to calculate the MCR and RCR. For the seven subjects, the mean serum hCG levels during the final $48 \mathrm{~h}$ of the low and the high infusion rates were $61.1 \pm 3.3$ and $237 \pm 16 \mathrm{ng} / \mathrm{ml}$ (mean \pm SEM), respectively. The MCR of hCG was $1.88 \pm 0.08 \mathrm{ml} / \mathrm{min}$ per $\mathrm{m}^{2}$ (Table $\mathrm{I}$ ), and there was no significant difference between the men and the women $\left(2.04 \pm 0.13\right.$ vs. $1.76 \pm 0.07 \mathrm{ml} / \mathrm{min}$ per $\left.\mathrm{m}^{2}\right)$. The

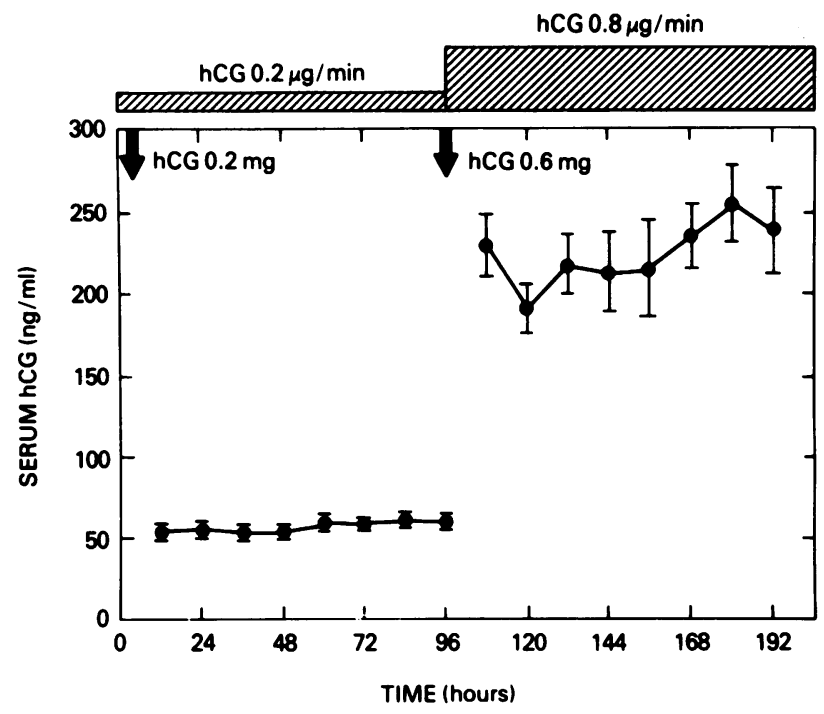

FIGURE 1 Serum levels of hCG achieved during the infusion of purified hCG at two different rates. An initial loading dose of $0.2 \mathrm{mg}$ hCG was administered by rapid intravenous injection, and a continuous intravenous infusion of hCG was maintained at $0.2 \mu \mathrm{g} / \mathrm{min}$ for $96 \mathrm{~h}$. At $96 \mathrm{~h}$, an additional rapid intravenous injection of $0.6 \mathrm{mg} \mathrm{hCG}$ was given, and the infusion rate was increased to $0.8 \mu \mathrm{g} / \mathrm{min}$ for an additional $96 \mathrm{~h}$. Blood specimens were obtained every $12 \mathrm{~h}$ during the $8 \mathrm{~d}$, and serum hCG was determined by radioimmunoassay. The closed circles are the means of the serum hCG levels in seven subjects; the vertical lines indicate the standard deviations. 
MCR of hCG at the low infusion rate did not differ significantly from that at the high infusion rate (Table I).

$R C R$ of hCG determined by the continuous infusion technique. For the seven subjects, the mean daily hCG excretion rates during days 3 and 4 of infusion were 58.6 and $233.9 \mu \mathrm{g} / 24 \mathrm{~h}$ for the low and high infusion rates, respectively (Table II). The percent of administered hCG excreted in urine varied among the subjects from 17 to $28 \%(21.6 \pm 1.1$, mean \pm SEM). The RCR of hCG determined in each subject was similar at the high and low infusion rates. The mean value for the RCR was $0.40 \pm 0.02 \mathrm{ml} / \mathrm{min}$ per $\mathrm{m}^{2}$. There was no significant difference in RCR between men and women $\left(0.42 \pm 0.05\right.$ vs. $0.39 \pm 0.03 \mathrm{ml} / \mathrm{min}$ per $\left.\mathrm{m}^{2}\right)$.

Characterization of serum and urine hCG immunoreactivity. Accumulation of hCG subunits or of immunoreactive metabolites in the serum or urine during the infusion could influence the accuracy of the hCG levels determined, and hence the MCR and RCR calculated from these values. Accordingly, we examined the nature of the immunoreactive hCG in serum and urine in order to ascertain the extent to which the total hCG immunoreactivity consisted of crossreactivity from hCG subunits or metabolites.

After Sephadex G-100 gel filtration of the base-line serum, no hCG $\beta$ or hCG $\alpha$ immunoreactivity was detected in any fraction (data not shown). Serum obtained on the final day of the 8-d continuous infusion of hCG was filtered on Sephadex G-100 and the levels of hCG $\alpha$ and hCG $\beta$ immunoreactivity in the fractions were determined (Fig. 2). Serum hCG $\beta$ immunoreactivity eluted in two positions: (a) a major peak (>90\% of the total immunoreactivity), which eluted from the column with the same $K_{\mathrm{av}}$ as the purified hCG and $(b)$ a minor peak $(<10 \%$ of the total immunoreactivity), which eluted with a smaller exclusion volume. No hCG $\beta$ immunoreactivity was apparent in the position where the free hCG $\beta$ subunit would have eluted from the column (Fig. 2). The larger apparent molecular size form of hCG immunoreactivity was not apparent in chromatographs of the hCG preparation incubated with or without the subjects' sera. It may

TABLE I

MCR of hCG Determined by Continuous Infusion of Highly Purified hCG

\begin{tabular}{|c|c|c|c|c|c|c|c|c|c|}
\hline Subject & Infusion rate & Sex & Height & Weight & $\begin{array}{l}\text { Body } \\
\text { surface } \\
\text { area }\end{array}$ & Infusion rate & Serum hCG* & \multicolumn{2}{|c|}{ hCG MCR } \\
\hline & & & $\mathrm{cm}$ & $k g$ & $m^{2}$ & $n g / m i n$ & $n g / m l$ & $\mathrm{ml} / \mathrm{min}$ & $\mathrm{ml} / \mathrm{min} / \mathrm{m}^{2}$ \\
\hline 1 & $\begin{array}{l}\text { Low } \\
\text { High }\end{array}$ & $\mathbf{M}$ & 176 & 65.4 & 1.80 & $\begin{array}{l}195.5 \pm 5.0 \ddagger \\
775.2 \pm 30.0\end{array}$ & $\begin{array}{r}55.2 \pm 1.5 \\
255.8 \pm 4.2\end{array}$ & $\begin{array}{l}3.56 \pm 0.18 \\
3.03 \pm 0.12\end{array}$ & $\begin{array}{l}1.98 \pm 0.10 \\
1.68 \pm 0.06\end{array}$ \\
\hline 2 & $\begin{array}{l}\text { Low } \\
\text { High }\end{array}$ & $\mathbf{M}$ & 181 & 69.3 & 1.89 & $\begin{array}{l}189.3 \pm 7.0 \\
750.7 \pm 25.7\end{array}$ & $\begin{array}{c}54.8 \pm 1.4 \\
192.0 \pm 23.0\end{array}$ & $\begin{array}{l}3.46 \pm 0.16 \\
4.19 \pm 0.78\end{array}$ & $\begin{array}{l}1.83 \pm 0.08 \\
2.22 \pm 0.41\end{array}$ \\
\hline 3 & $\begin{array}{l}\text { Low } \\
\text { High }\end{array}$ & $\mathbf{M}$ & 182 & 80.8 & 2.02 & $\begin{array}{l}193.7 \pm 10.3 \\
789.0 \pm 34.2\end{array}$ & $\begin{array}{r}44.6 \pm 1.4 \\
168.2 \pm 9.0\end{array}$ & $\begin{array}{l}4.35 \pm 0.22 \\
4.76 \pm 0.45\end{array}$ & $\begin{array}{l}2.16 \pm 0.11 \\
2.36 \pm 0.22\end{array}$ \\
\hline 4 & $\begin{array}{l}\text { Low } \\
\text { High }\end{array}$ & F & 162 & 61.7 & 1.66 & $\begin{array}{l}185.2 \pm 3.7 \\
862.4 \pm 6.5\end{array}$ & $\begin{array}{c}70.7 \pm 3.2 \\
288.8 \pm 12.2\end{array}$ & $\begin{array}{l}2.63 \pm 0.10 \\
3.00 \pm 0.14\end{array}$ & $\begin{array}{l}1.58 \pm 0.06 \\
1.81 \pm 0.08\end{array}$ \\
\hline 5 & $\begin{array}{l}\text { Low } \\
\text { High }\end{array}$ & $\mathbf{F}$ & 156 & 53.2 & 1.51 & $\begin{array}{c}201.0 \pm 3.8 \\
-\end{array}$ & $\begin{array}{c}75.5 \pm 1.6 \\
-\end{array}$ & $\begin{array}{c}2.66 \pm 0.03 \\
-\end{array}$ & $\begin{array}{c}1.76 \pm 0.02 \\
-\end{array}$ \\
\hline 6 & $\begin{array}{l}\text { Low } \\
\text { High }\end{array}$ & $\mathbf{F}$ & 154 & 54.5 & 1.51 & $\begin{array}{l}161.9 \pm 20.2 \\
723.8 \pm 22.8\end{array}$ & $\begin{array}{c}71.6 \pm 4.0 \\
280.2 \pm 10.6\end{array}$ & $\begin{array}{l}2.31 \pm 0.36 \\
2.60 \pm 0.17\end{array}$ & $\begin{array}{l}1.53 \pm 0.24 \\
1.72 \pm 0.12\end{array}$ \\
\hline 7 & $\begin{array}{l}\text { Low } \\
\text { High }\end{array}$ & $\mathbf{F}$ & 164 & 57.5 & 1.62 & $\begin{array}{c}175.0 \pm 6.0 \\
-\end{array}$ & $\begin{array}{c}55.0 \pm 2.2 \\
-\end{array}$ & $\begin{array}{c}3.19 \pm 0.10 \\
-\end{array}$ & $\begin{array}{c}1.97 \pm 0.06 \\
-\end{array}$ \\
\hline & $\begin{array}{l}\text { Low }(n=7) \\
\text { High }(n=5)\end{array}$ & & & & & & & $\begin{array}{l}3.17 \pm 0.26 \\
3.52 \pm 0.41\end{array}$ & $\begin{array}{l}1.83 \pm 0.09 \\
1.95 \pm 0.14\end{array}$ \\
\hline & Combined $(n=12)$ & & & & & & & $3.31 \pm 0.23$ & $1.88 \pm 0.08$ \\
\hline
\end{tabular}

* Levels were calculated by averaging serum levels during days 3 and 4 of the hCG infusion.

$\$$ Mean \pm SEM of values obtained during four consecutive 12-h infusion periods. 
TABLE II

RCR of hCG Determined by Continuous Infusion of Highly Purified hCG

\begin{tabular}{|c|c|c|c|c|c|c|c|}
\hline Subject & Infusion rate & Sex & $\begin{array}{l}\text { Body surface } \\
\text { area }\end{array}$ & Serum hCG* & Urine hCG & \multicolumn{2}{|c|}{ hCG RCR } \\
\hline & & & $m^{2}$ & $n g / m l$ & $\mu g / 24 h$ & $\mathrm{ml} / \mathrm{min}$ & $\mathrm{ml} / \mathrm{min} / \mathrm{m}^{2}$ \\
\hline 1 & $\begin{array}{l}\text { Low } \\
\text { High }\end{array}$ & $\mathbf{M}$ & 1.80 & $\begin{aligned} 55.2 \pm 1.5 \\
255.8 \pm 4.2\end{aligned}$ & $\begin{array}{c}52.3 \S \\
242.4\end{array}$ & $\begin{array}{l}0.658 \pm 0.043 \\
0.658 \pm 0.030\end{array}$ & $\begin{array}{l}0.348 \pm 0.022 \\
0.348 \pm 0.016\end{array}$ \\
\hline 2 & $\begin{array}{l}\text { Low } \\
\text { High }\end{array}$ & $\mathbf{M}$ & 1.89 & $\begin{array}{c}54.8 \pm 1.4 \\
192.0 \pm 23.0\end{array}$ & $\begin{array}{r}55.6 \\
184.0\end{array}$ & $\begin{array}{l}0.706 \pm 0.038 \\
0.662 \pm 0.020\end{array}$ & $\begin{array}{l}0.374 \pm 0.020 \\
0.350 \pm 0.010\end{array}$ \\
\hline 3 & $\begin{array}{l}\text { Low } \\
\text { High }\end{array}$ & $\mathbf{M}$ & 2.02 & $\begin{array}{r}44.6 \pm 1.4 \\
168.2 \pm 9.0\end{array}$ & $\begin{array}{r}52.2 \\
245.5\end{array}$ & $\begin{array}{l}0.808 \pm 0.062 \\
1.026 \pm 0.226\end{array}$ & $\begin{array}{l}0.400 \pm 0.030 \\
0.508 \pm 0.112\end{array}$ \\
\hline 4 & $\begin{array}{l}\text { Low } \\
\text { High }\end{array}$ & $\mathbf{F}$ & 1.66 & $\begin{array}{c}70.7 \pm 3.2 \\
288.8 \pm 12.2\end{array}$ & $\begin{array}{r}65.3 \\
208.6\end{array}$ & $\begin{array}{l}0.640 \pm 0.066 \\
0.506 \pm 0.048\end{array}$ & $\begin{array}{l}0.386 \pm 0.040 \\
0.304 \pm 0.028\end{array}$ \\
\hline 5 & $\begin{array}{l}\text { Low } \\
\text { High }\end{array}$ & $\mathbf{F}$ & 1.51 & $\begin{array}{c}75.5 \pm 1.6 \\
-\end{array}$ & $\begin{array}{c}62.0 \\
-\end{array}$ & $\begin{array}{c}0.572 \pm 0.057 \\
-\end{array}$ & $\begin{array}{c}0.378 \pm 0.038 \\
-\end{array}$ \\
\hline 6 & $\begin{array}{l}\text { Low } \\
\text { High }\end{array}$ & $\mathrm{F}$ & 1.51 & $\begin{array}{c}71.6 \pm 4.0 \\
280.2 \pm 10.6\end{array}$ & $\begin{array}{r}52.2 \\
288.6\end{array}$ & $\begin{array}{l}0.506 \pm 0.018 \\
0.719 \pm 0.098\end{array}$ & $\begin{array}{l}0.335 \pm 0.012 \\
0.476 \pm 0.064\end{array}$ \\
\hline 7 & $\begin{array}{l}\text { Low } \\
\text { High }\end{array}$ & $\mathrm{F}$ & 1.62 & $\begin{array}{c}55.0 \pm 2.2 \\
-\end{array}$ & $\begin{array}{c}70.8 \\
-\end{array}$ & $\begin{array}{c}0.894 \pm 0.050 \\
-\end{array}$ & $\begin{array}{c}0.552 \pm 0.031 \\
-\end{array}$ \\
\hline & $\begin{array}{l}\text { Low }(n=7) \\
\text { High }(n=5)\end{array}$ & & & & & $\begin{array}{l}0.683 \pm 0.050 \\
0.714 \pm 0.085\end{array}$ & $\begin{array}{l}0.396 \pm 0.027 \\
0.397 \pm 0.040\end{array}$ \\
\hline & Combined $(n=12)$ & & & & & $0.696 \pm 0.044$ & $0.397 \pm 0.022$ \\
\hline
\end{tabular}

* Data repeated from Table I for convenience.

$\$$ Mean \pm SEM of values obtained during four consecutive 12-h infusion periods.

$\S$ Mean of values obtained on 24 -h specimens collected on days 3 and 4 .

represent some form of hCG complexed with serum proteins, as the relative proportions of hCG $\alpha$ and hCG $\beta$ immunoreactivity were similar to that of the intact hCG molecule. Judging from the size of this minor peak relative to the size of the hCG peak, the serum hCG levels determined by radioimmunoassay would overestimate the actual hCG concentration only slightly $(<10 \%)$. With regard to other hCG-related immunoreactive substances, after $8 \mathrm{~d}$ of continuous infusion of purified hCG, the only detectable hCG $\alpha$ immunoreactivity was found in the fractions which contained hCG $\beta$ immunoreactivity; none was observed in the position where free hCG $\alpha$ would have eluted from the column (Fig. 2).

Gel filtration of the urine obtained on the 8th $d$ of the hCG infusion revealed that the vast majority of the hCG $\beta$ immunoreactivity eluted in fractions corresponding to intact hCG (Fig. 3, upper panel). There was no apparent free hCG $\beta$ subunit of a size similar to that of authentic hCG $\beta$ in any of the subjects. However, the urine of the subject illustrated here did contain a small amount of hCG $\beta$ immunoreactivity which eluted from the column with a larger exclusion volume than hCG, hCG $\alpha$, or hCG $\beta$. This substance with hCG $\beta$ immunoreactivity had a $K_{\text {av }}$ on this column, which was essentially identical with that of the discrete degradation product of the hCG $\beta$ subunit that we have described previously (26). However, this small molecular size form of hCG $\beta$ immunoreactivity constituted a minute portion of the total hCG $\beta$ immunoreactivity eluted from the column and was not detected in the eluate obtained from gel filtration of the urine of the other six subjects. Hence, with the infusion of purified hCG, the overwhelming majority of the hCG $\beta$ immunoreactivity excreted in urine was hCG itself.

When base-line urine was gel filtered, minor amounts of hCG $\alpha$ immunoreactivity were observed in the position corresponding to that of free hCG $\alpha$ (Fig. 3, lower panel) confirming our previous experience (22). After $8 \mathrm{~d}$ of continuous infusion of hCG, urinary hCG $\alpha$ immunoreactivity eluted in the position corresponding to that of intact hCG, as expected; the peak corresponding to free hCG $\alpha$ did not appear to have changed 


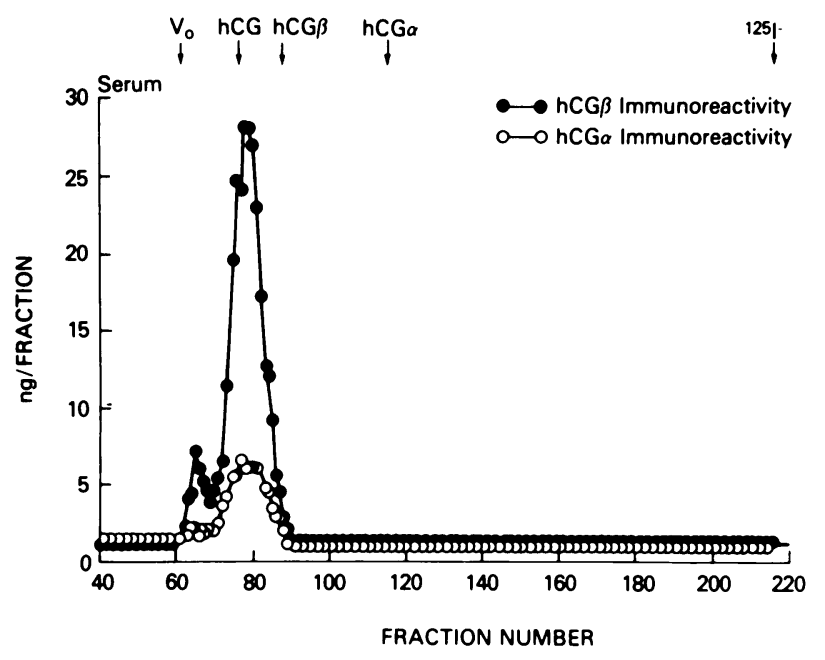

Figure 2 Sephadex G-100 gel filtration of serum obtained from a male subject on day 8 of continuous intravenous infusion of purified hCG. Serum $(2.0 \mathrm{ml})$ was applied to a Sephadex G-100 column $(83.5 \times 2.6 \mathrm{~cm})$ and was eluted with PBS by upward filtration at $25 \mathrm{ml} / \mathrm{h}$. Fractions of $2.3 \mathrm{ml}$ were collected and aliquots assayed for hCG $\beta$ and $\mathrm{hCG} \alpha$ immunoreactivity. $V_{0}$ is the void volume and ${ }^{125} I^{-}$indicates the position of the salt peak. The positions of authentic $\mathrm{hCG}, \mathrm{hCG} \beta$, and $\mathrm{hCG} \alpha$ are indicated.

appreciably (Fig. 3). Thus, there is no evidence for degradation of hCG to an hCG $\alpha$-like material, similar to that which has been reported to exist in pregnancy serum and urine $(11,12,14)$.

The hCG $\beta$ carboxy-terminal peptide radioimmunoassay was used to obtain another estimate of the quantity and immunological character of the hCG in the serum and urine specimens obtained during the continuous infusion of purified hCG. We reasoned that if the infused hCG were unaltered, and if negligible quantities of immunoreactive metabolites had accumulated, the ratio of the carboxy-terminal peptide immunological determinant level to the conformational (SB6) determinant level should be unity, i.e., equal to that in the purified hCG. The levels of these two determinants were indeed nearly identical in serum (Fig. 4) and in urine (Fig. 5). Therefore, clearance calculations based on hCG levels measured by radioimmunoassay using carboxy-terminal peptide determinant antiserum were not significantly different from those measured employing hCG $\beta$ conformational determinant antiserum (MCR, $1.91 \pm 0.11$ vs. $1.88 \pm 0.08$ $\mathrm{ml} / \mathrm{min}$ per $\mathrm{m}^{2}$; RCR, $0.38 \pm 0.03$ vs. $0.40 \pm 0.02 \mathrm{ml} /$ $\min$ per $\mathrm{m}^{2}$ ).

The slopes of the dose-response curves of the serum and urine specimens collected during infusion of hCG were not significantly different from that of authentic hCG in the hCG radioimmunoassay. The immunoreactive hCG material in both serum and urine

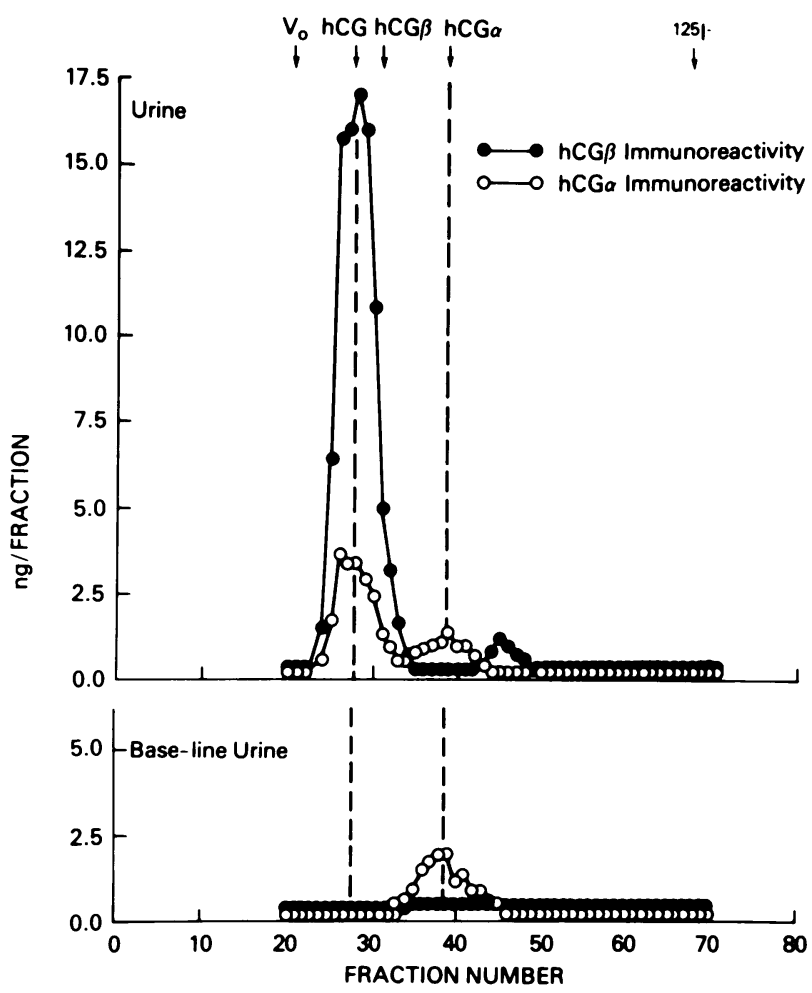

Figure 3 Sephadex G-100 gel filtration of urine obtained from a male subject on day 8 of continuous intravenous infusion of purified hCG (upper panel), and base-line urine from the same subject (lower panel). Urine $(1.0 \mathrm{ml})$ was applied to a Sephadex G-100 column $(69.5 \times 1.6 \mathrm{~cm})$ and was eluted with PBS by upward flow at $25 \mathrm{ml} / \mathrm{h}$. Fractions of 2.3 $\mathrm{ml}$ were collected and aliquots assayed for hCG $\beta$ and hCG $\alpha$ immunoreactivity. $V_{0}$ is the void volume and ${ }^{125} I^{-}$indicates the salt peak. The positions of authentic hCG, hCG $\beta$, and $\mathrm{hCG} \alpha$ are indicated.

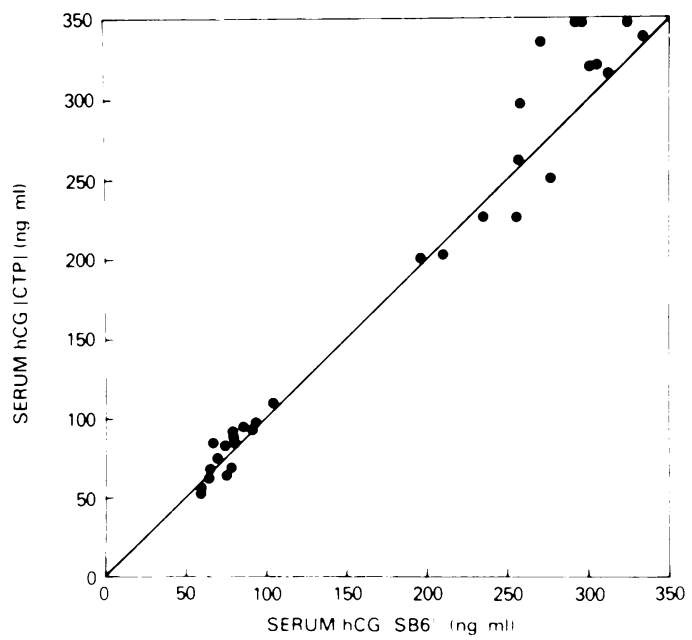

Figure 4 Correlation of hCG levels determined in serum by antiserum to the hCG $\beta$ carboxy-terminal peptide determinant (CTP) and by antiserum to the hCG $\beta$ subunit conformational determinant (SB6). The line of unity is drawn. $r=0.98 ; P$ $<0.001$. 


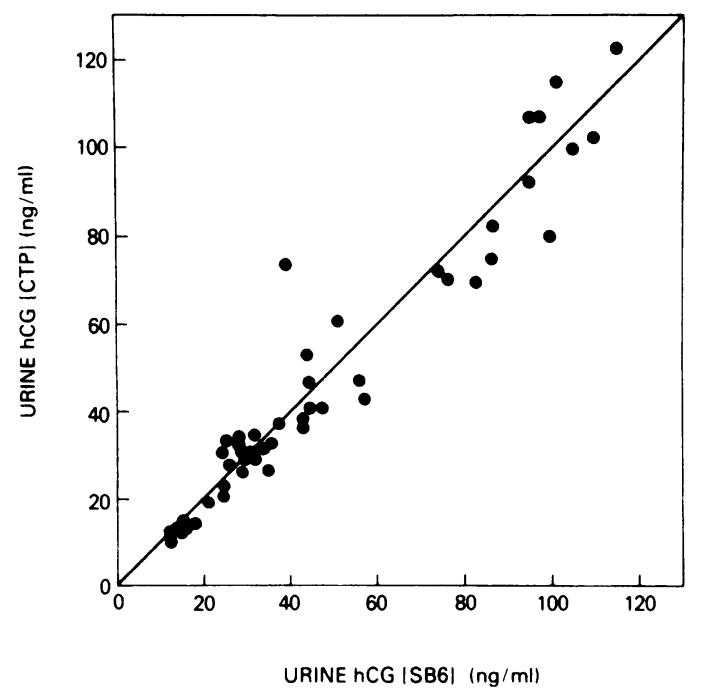

FIGURE 5 Correlation of hCG levels determined in urine by antiserum to the hCG $\beta$ carboxy-terminal peptide determinant (CTP) and by antiserum to the hCG $\beta$ subunit conformational determinant (SB6). The line of unity is drawn. $r=0.96$; $P<0.001$.

adsorbed quantitatively to Con A-Sepharose, indicating that no deglycosylated hCG had accumulated.

In summary, when purified hCG was administered to normal subjects by continuous infusion to achieve steady state levels, the vast majority of the accumulated immunoreactive material detected in serum and urine by our radioimmunoassays was apparently intact hCG. Parenthetically, there may be other peptide fragments present which lacked cross-reactivity in these radioimmunoassays.

Levels of hCG in serum after single injection of $h C G$. Base-line serum hCG levels (hCG $\beta$ determinant radioimmunoassay) were at or below the detection limit of the assay $(\leq 1.0 \mathrm{ng} / \mathrm{ml})$. After rapid intravenous injection of $1.0 \mathrm{mg}$ of purified hCG the initial serum levels of hCG achieved were $300-400 \mathrm{ng} / \mathrm{ml}$. Fig. 6 shows the mean hCG levels of six subjects during $7 \mathrm{~d}$ after injection. The serum disappearance curve is curvilinear on a semilog plot. The kinetic parameters of the computer-derived biexponential curves for each subject are given in Table III. The initial volume of distribution, when corrected for body size, was the same for men and women, and was similar to plasma volume. The rapid component $t_{1 / 2}$ was $\sim 6 \mathrm{~h}$, and the slow component $\mathrm{t}_{1 / 2}$ was $\sim 36 \mathrm{~h}$.

MCR and RCR of hCG determined by the single injection technique. The parameters of the serum disappearance curve of hCG were used to calculate the MCR of hCG after single intravenous injection of purified hCG in each subject. The mean MCR calculated for the group was $1.61 \pm 0.09 \mathrm{ml} / \mathrm{min}$ per $\mathrm{m}^{2}$ (Table IV). The urinary excretion of hCG was great-

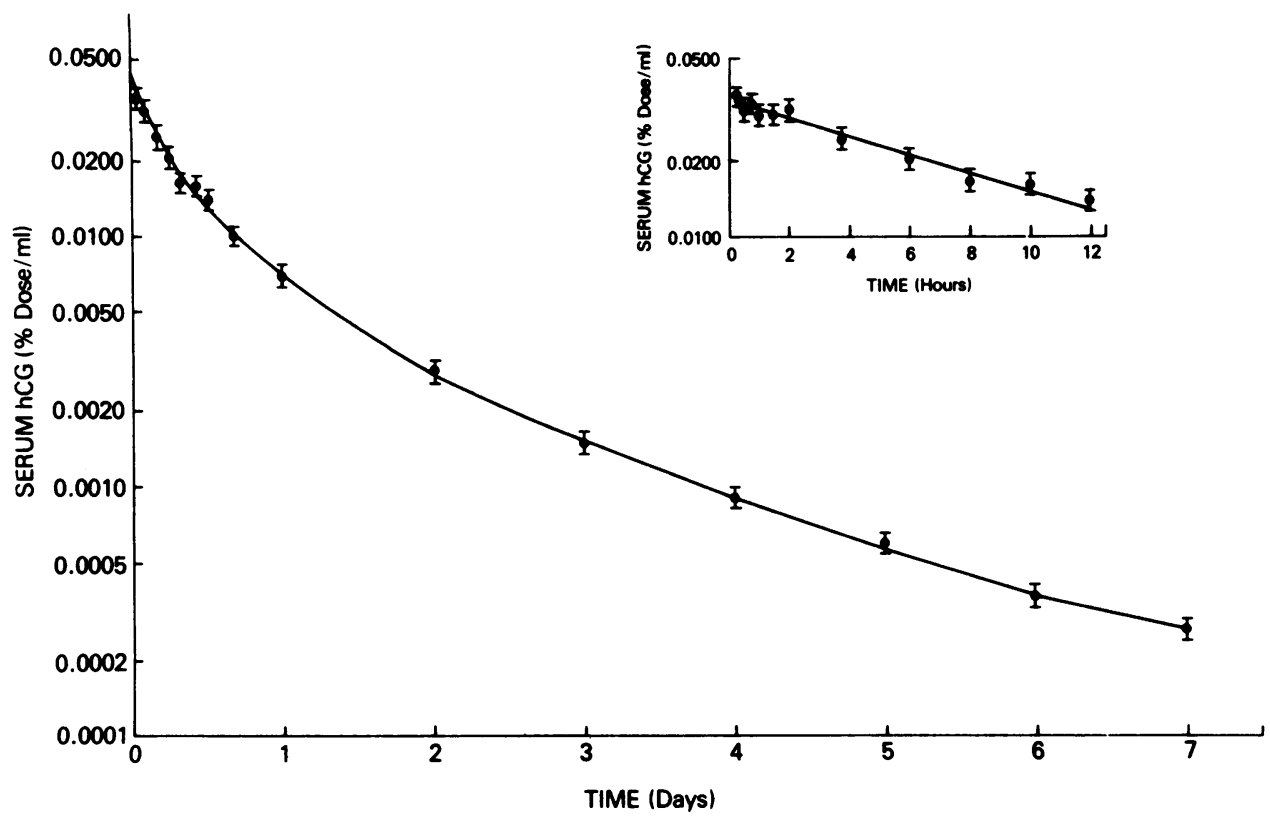

FIGURE 6 Disappearance of hCG from serum after injection of highly purified hCG $(1.0 \mathrm{mg})$ in six normal subjects. Blood specimens were obtained at various times after rapid intravenous injection of hCG, and serum levels of hCG were measured by radioimmunoassay. Closed circles represent the mean serum hCG levels, expressed as a percentage of the administered dose per milliliter; the vertical lines indicate the SEM. The insert provides more detail of the disappearance during the first $12 \mathrm{~h}$ after injection. 
TABLE III

Kinetic Parameters of hCG Determined by Single Intravenous Injections of $1 \mathrm{mg}$ of Highly Purified hCG

\begin{tabular}{|c|c|c|c|c|c|c|c|c|c|c|}
\hline \multirow{3}{*}{ Subject } & \multirow{3}{*}{ Sex } & \multirow{3}{*}{$\begin{array}{c}\begin{array}{c}\text { Body } \\
\text { surface } \\
\text { area }\end{array} \\
m^{2}\end{array}$} & \multirow{3}{*}{$\frac{\mathrm{A}}{\% \text { dose } / m l}$} & \multirow{3}{*}{$\frac{\alpha}{h^{-1}}$} & \multirow{3}{*}{$\frac{\text { B }}{\% \text { dose } / m l}$} & \multirow{3}{*}{$\frac{\beta}{h^{-1}}$} & \multicolumn{4}{|c|}{$t_{1 / 2}$} \\
\hline & & & & & & & \multirow{2}{*}{$\frac{\text { Fast }}{h}$} & \multirow{2}{*}{$\frac{\text { Slow }}{h}$} & \multicolumn{2}{|c|}{$v_{d}$} \\
\hline & & & & & & & & & $m l$ & $m l / m^{2}$ \\
\hline 8 & $\mathbf{M}$ & 1.77 & 0.0305 & 0.116 & 0.0069 & 0.0228 & 5.95 & 30.2 & 2674 & 1511 \\
\hline 9 & M & 1.69 & 0.0282 & 0.101 & 0.0052 & 0.0198 & 6.83 & 34.9 & 2994 & 1772 \\
\hline 10 & M & 1.98 & 0.0233 & 0.082 & 0.0017 & 0.0096 & 8.45 & 74.2 & 4000 & 2020 \\
\hline 11 & $\mathrm{~F}$ & 1.61 & 0.0193 & 0.120 & 0.0121 & 0.0234 & 5.77 & 29.7 & 3185 & 1978 \\
\hline 12 & $\mathbf{F}$ & 1.95 & 0.0228 & 0.165 & 0.0132 & 0.0324 & 4.20 & 21.3 & 2778 & 1425 \\
\hline 13 & $\mathbf{F}$ & 1.62 & 0.0294 & 0.149 & 0.0187 & 0.0294 & 4.63 & 23.4 & 2079 & 1283 \\
\hline Mean & & 1.77 & 0.0256 & 0.122 & 0.0096 & 0.0229 & 5.97 & 35.6 & 2952 & 1665 \\
\hline SEM & & 0.07 & 0.0018 & 0.012 & 0.0025 & 0.0033 & 0.63 & 8.0 & 260 & 124 \\
\hline
\end{tabular}

est on the 1st d after injection of hCG, and declined progressively thereafter. To calculate the RCR of hCG, we used the urinary excretion of hCG measured during the first $3 \mathrm{~d}$ after injection and the serum concentration curve integrated during the same $3 \mathrm{~d}$. As shown in Table IV, the RCR of hCG in these subjects was $0.49 \pm 0.05 \mathrm{ml} / \mathrm{min}$ per $\mathrm{m}^{2}$.

\section{DISCUSSION}

Using purified hCG and a continuous infusion technique, we have determined that the MCR of hCG is $\sim 2 \mathrm{ml} / \mathrm{min}$ per $\mathrm{m}^{2}$, and that the MCR is independent of the serum hCG level over the range of $60-240 \mathrm{ng} / \mathrm{ml}$. The MCR, expressed in terms of body surface area, does not differ significantly between healthy young men and women. Similarly, the RCR of hCG, $\sim 0.40$ $\mathrm{ml} / \mathrm{min}$ per $\mathrm{m}^{2}$, is independent of the serum hCG level, and is the same for men and women. Renal excretion accounts for only $20 \%$ of the total disposal of purified hCG. The pathways for the other $80 \%$ of the disposal remain unaccounted for, but presumably involve uptake and degradation by hepatic and renal tissue (27); in addition, although it is clear that binding to gonadal receptors accounts for some of the metabolism of hCG (27), this pathway is likely to be of minor quantitative significance.

We gave purified hCG by continuous infusion, and our value for the MCR of hCG is $3.31 \pm 0.23 \mathrm{ml} / \mathrm{min}$ (or $1.88 \pm 0.08 \mathrm{ml} / \mathrm{min}$ per $\mathrm{m}^{2}$ ). In contrast, previous studies of hCG metabolism employed analysis of its disappearance after a single injection of crude preparations of hCG $(2,3,5)$, or after removal of hCG-producing tissue, e.g., delivery of the placenta $(1,4)$. For example, Wide et al. (2) calculated an MCR based on bioassay measurement of hCG of $2.33 \mathrm{ml} / \mathrm{min}$; when a radioimmunoassay was used to measure hCG, these authors found a substantially different value of the MCR,

TABLE IV

$R C R$ and MCR of hCG Determined by Single Intravenous Injection of Purified hCG

\begin{tabular}{cccccccc}
\hline Subject & Sex & $\begin{array}{c}\text { Body surface } \\
\text { area }\end{array}$ & $\mathrm{U}^{*}$ & $\int_{0}^{3} \mathrm{Cdt}$ & & $\mathrm{RCR}$ & $\mathrm{MCR}$ \\
\hline & & $m^{2}$ & $n g / 3 d$ & $\mathrm{ng} \cdot \mathrm{min} / \mathrm{ml}$ & $\mathrm{ml} / \mathrm{min}$ & $\mathrm{ml} / \mathrm{min} / \mathrm{m}^{2}$ & $\mathrm{ml} / \mathrm{min} / \mathrm{m}^{2}$ \\
8 & $\mathrm{M}$ & 1.77 & 284,704 & 210.22 & 0.94 & 0.53 & 1.68 \\
9 & $\mathrm{M}$ & 1.69 & 292,766 & 198.91 & 1.02 & 0.60 & 1.83 \\
10 & $\mathrm{M}$ & 1.98 & 283,195 & 155.35 & 1.27 & 0.64 & 1.81 \\
11 & $\mathrm{~F}$ & 1.61 & 215,758 & 242.39 & 0.62 & 0.38 & 1.53 \\
12 & $\mathrm{~F}$ & 1.95 & 240,326 & 210.32 & 0.79 & 0.41 & 1.57 \\
13 & $\mathrm{~F}$ & 1.62 & 294,430 & 313.79 & 0.65 & 0.40 & 1.24 \\
Mean & & & & & 0.88 & 0.49 & 1.61 \\
SEM & & & & & 0.10 & 0.05 & 0.09 \\
\hline
\end{tabular}

* $\mathrm{U}=$ quantity of hCG excreted during the $3 \mathrm{~d}$ after injection of purified hCG. $\$ \int_{0}^{3} \mathrm{C} d t=$ serum hCG concentration integrated over the $3 \mathrm{~d}$ after injection of purified hCG. 
$5.83 \mathrm{ml} / \mathrm{min}$. Presumably, the different potency estimates by bioassay and radioimmunoassay were due to heterogeneity of the circulating hCG-related material. Further, some forms of immunologically active, but biologically inactive hCG-related molecules may have a considerably more rapid clearance than authentic hCG; examples are hCG $\alpha$ and hCG $\beta$ (28). Rizkallah et al. (3) used a radioimmunoassay to measure hCG after injection of a crude hCG preparation and found MCR of $2.35 \mathrm{ml} / \mathrm{min}$ (men) and $2.68 \mathrm{ml} / \mathrm{min}$ (women). Sowers et al. (5) used a crude commercial preparation of hCG, which they indicated was composed of immunoreactive impurities such as the hCG $\beta$ subunit. These contaminants may explain in part why their calculated MCR of hCG (14 ml/min) was so high.

We also administered highly purified hCG by rapid intravenous injection to permit a comparison of our curve parameters for highly purified hCG with those available in the literature. Analysis of the disappearance curve of hCG in our studies revealed it to be a multiexponential function; this is similar to observations in most previous reports $(1,3-5)$. Using the kinetic parameters derived for each individual, we calculated the apparent initial volume of distribution to be $2,952 \pm 260 \mathrm{ml}$ (or $1,665 \pm 124 \mathrm{ml} / \mathrm{m}^{2}$ ). This value is similar to the estimated plasma volume of our subjects, and reflects the general experience with other glycoprotein hormones (29-31). Wide et al. (2) derived values of $V_{d}$ of injected hCG of $1,664 \mathrm{ml}$ by bioassay and $3,680 \mathrm{ml}$ by radioimmunoassay. Rizkallah et al. (3) found values ranging from 1,750 to $2,830 \mathrm{ml}$. The rapid and slow component half-lives of serum hCG disappearance in our subjects were $6.0 \pm 0.6$ and $36 \pm 8 \mathrm{~h}$, respectively. Midgley and Jaffe (1) found similar mean values after delivery in pregnant women. These workers also injected hCG in one nonpregnant woman and found a slow component half-life of $32 \mathrm{~h}$. Rizkallah et al. (3) reported values of 5 and $24 \mathrm{~h}$ for the rapid and slow component half-lives; the values for men and women were the same. Yen et al. (4) measured the postpartum disappearance of hCG by radioimmunoassay, and reported a rapid half-life of $11 \mathrm{~h}$ and a slow half-life of $23.4 \mathrm{~h}$. Wide et al. (2) detected only a single exponential disappearance after injection of hCG, with a half-life of 6-10 h; however, the latest time point at which the hCG level was determined was $24 \mathrm{~h}$ in two subjects and $5 \mathrm{~h}$ in the third.

Our value for the RCR of hCG is $0.70 \pm 0.04 \mathrm{ml} / \mathrm{min}$ (or $0.40 \pm 0.02 \mathrm{ml} / \mathrm{min} / \mathrm{m}^{2}$ ). Wide et al. (2) reported that the RCR was $0.70 \mathrm{ml} / \mathrm{min}$ when hCG is measured by radioimmunoassay, and $0.36 \mathrm{ml} / \mathrm{min}$ when hCG is measured by bioassay in male rats. Gastineau et al. (8), using a rat ovarian hyperemia bioassay to measure serum and urinary hCG, found a value of $0.38 \mathrm{ml} / \mathrm{min}$ during normal pregnancy; using a rat prostate weight bioassay, Loraine (6) reported RCR values during pregnancy of $0.95 \pm 0.17 \mathrm{ml} / \mathrm{min}$ (SD). Midgley and Jaffe (1) found RCR values by radioimmunoassay which ranged from 0.59 to $1.75 \mathrm{ml} / \mathrm{min}$ after normal pregnancy and delivery; Johnson et al. (7) measured serum and urinary hCG by ovarian hyperemia bioassay and calculated the RCR to be $0.47 \mathrm{ml} / \mathrm{min}$. Sowers et al. (5) also estimated the RCR of hCG by radioimmunoassay after injection of their crude hCG preparation. Their value of $4 \mathrm{ml} / \mathrm{min}$ is at great variance with the previously published data, as well as with our own.

We have recently reported studies of the metabolism of the purified hCG subunits in humans $(22,28)$; in Table V, the kinetic parameters of hCG metabolism are compared with those of hCG $\alpha$ and hCG $\beta$. It can be appreciated that the disappearance curve parameters $A$ and B are not substantially different for the three

TABLE V

Comparison of Kinetic Parameters and Clearance Rates of $h C G, h C G \beta$, and $h C G \alpha$ in Man

\begin{tabular}{lccc}
\hline & hCG $(n=6)$ & hCG $\beta(n=13)^{*}$ & hCG $\alpha(n=8)^{*}$ \\
\hline A, \% dose $/ \mathrm{ml}$ & $0.0256 \pm 0.0018 \ddagger$ & $0.0251 \pm 0.0021$ & $0.0273 \pm 0.0025$ \\
$\alpha, h^{-1}$ & $0.122 \pm 0.012$ & $1.032 \pm 0.042$ & $3.276 \pm 0.192$ \\
B, \% dose $/ \mathrm{ml}$ & $0.0096 \pm 0.0025$ & $0.0041 \pm 0.0010$ & $0.0055 \pm 0.0013$ \\
$\beta, h^{-1}$ & $0.0229 \pm 0.0033$ & $0.174 \pm 0.030$ & $0.546 \pm 0.138$ \\
$\mathrm{t}_{\mathbf{1} / 2}, h$ & & & \\
$\quad$ Fast & $5.97 \pm 0.63$ & $0.68 \pm 0.03$ & $0.22 \pm 0.02$ \\
Slow & $35.6 \pm 8.0$ & $3.93 \pm 0.68$ & $1.27 \pm 0.32$ \\
$\mathrm{~V}_{\mathrm{d}}, \mathrm{ml} / \mathrm{m}^{2}$ & $1665 \pm 124$ & $1958 \pm 131$ & $1729 \pm 99$ \\
$\mathrm{MCR}, \mathrm{ml} / \mathrm{min} / \mathrm{m}^{2}$ & $1.88 \pm 0.08$ & $19.0 \pm 0.7$ & $49.7 \pm 1.6$ \\
RCR, $\mathrm{ml} / \mathrm{min} / \mathrm{m}^{2}$ & $0.40 \pm 0.02$ & $0.13 \pm 0.02$ & $0.16 \pm 0.02$ \\
RCR/MCR $\times 100 \%$ & $21.7 \pm 1.4$ & $0.68 \pm 0.11$ & $0.33 \pm 0.04$ \\
\hline
\end{tabular}

* Values for hCG $\beta$ and hCG $\alpha$ are calculated from our previously published data $(22,28)$. $\$$ Mean \pm SEM. 
molecules; hence, the initial volumes of distribution are not significantly different, and not unexpectedly, they approximate the plasma volume. It is readily apparent that the slopes of the fast and slow components of the disappearance curves ( $\alpha$ and $\beta$, respectively), differ significantly among the three molecules, increasing in the order hCG $\ll$ hCG $\beta<\mathrm{hCG} \alpha$; consequently, the half-lives of disappearance decrease in the order hCG $\gg$ hCG $\beta>\mathrm{hCG} \alpha$. As a result of these relationships, the MCR of hCG:hCG $\beta$ :hCG $\alpha$ assumes the proportions 1:10:25. This relationship suggests that other factors in addition to the high proportion of carbohydrate are responsible for the slow MCR of hCG. The hCG $\beta$ subunit contains relatively more carbohydrate and sialic acid in proportion to its weight than does the intact hCG molecule (32), and yet its MCR is 10 -fold greater than that of hCG. While the absolute values of the half-lives of hCG, hCG $\beta$, and hCG $\alpha$ determined in man are considerably different from those determined after injection of these molecules in rats, the half-lives of disappearance in rats show the same relationships as in man, namely decreasing in the order hCG $\gg$ hCG $\beta>$ hCG $\alpha(27)$.

The RCR do not show the same relationships as the MCR. The RCR of hCG is approximately two to three times greater than that of either of its subunits. Therefore, the more rapid MCR of hCG $\alpha$ and hCG $\beta$ are not attributable to enhanced renal excretion. Our data show that $20 \%$ of the metabolic disposal of hCG is accounted for by urinary excretion but $<1 \%$ of the disposal of hCG $\alpha$ and hCG $\beta$ is accounted for by urinary excretion. The structural features that determine these relationships are unknown.

Despite possessing structures which are basically similar to that of hCG, the pituitary glycoprotein hormones have MCR which are considerably greater than that of hCG (29-31, 33-35). The differences in MCR among these hormones are not necessarily attributable solely to their differences in carbohydrate composition. For example, the MCR of human luteinizing hormone $(\mathrm{hLH})$ is much greater than that of $\mathrm{hCG}$, but about the same as that of hCG $\beta(28-31,33)$. Yet, both hCG and hCG $\beta$ are much richer in sialic acid and other carbohydrate residues than hLH. The amino acid sequence of the hLH $\beta$ subunit exhibits $\sim 80 \%$ homology with hCG $\beta$, but hLH $\beta$ lacks the 30 amino acid sequence at its carboxy-terminus, which is characteristic of hCG $\beta$ (32). Further study is necessary to clarify how these various differences in structure account for the much lower MCR of the hCG molecule in comparison to hLH and the other pituitary glycoprotein hormones.

\section{ACKNOWLEDGMENTS}

We are grateful to Dr. S. M. Harman and Dr. M. R. Blackman for their help with the analysis of the data and critical review of the manuscript. Ms. Y. Wilson prepared the columns that were used in the gel filtration studies.

\section{REFERENCES}

1. Midgley, A. R., Jr., and R. B. Jaffe. 1968. Regulation of human gonadotropins: disappearance of human chorionic gonadotropin following delivery. J. Clin. Endocrinol. Metab. 28: 1712-1718.

2. Wide, L., E. Johannisson, K-G. Tillinger, and E. Diczfalusy. 1968. Metabolic clearance of human chorionic gonadotrophin administered to nonpregnant women. Acta Endocrinol. 59: 579-594.

3. Rizkallah, T., E. Gurpide, and R. L. Vande Wiele. 1969. Metabolism of hCG in man. J. Clin. Endocrinol. Metab. 29: $92-100$.

4. Yen, S. S. C., O. Llerena, B. Little, and O. H. Pearson. 1968. Disappearance rates of endogenous luteinizing hormone and chorionic gonadotropin in man. J. Clin. Endocrinol. Metab. 28: 1763-1767.

5. Sowers, J. R., A. E. Pekary, J. M. Hershman, M. Kanter, and J. J. DiStefano III. 1979. Metabolism of exogenous human chorionic gonadotrophin in men. J. Endocrinol. 80: $83-89$.

6. Loraine, J. A. 1950. The renal clearance of chorionic gonadotrophin in normal and pathological pregnancy. Q. J. Exp. Physiol. 36: 11-20.

7. Johnson, C. E., A. Albert, and R. B. Wilson. 1950. Renal and extrarenal disposal of chorionic gonadotropin in the immediate postpartum period.J. Clin. Endocrinol. Metab. 10: $371-380$.

8. Gastineau, C. F., A. Albert, and L. M. Randall. 1949. The renal clearance of chorionic gonadotropic hormone in pregnancy, in neoplasm of the testis and in hydatidiform mole. J. Clin. Endocrinol. Metab. 9: 615-621.

9. Lloyd, C. W., E. C. Hughs, M. L. Eva, and J. Lobotsky. 1949. The urinary excretion of chorionic gonadotropin by human females following parenteral administration of aqueous or beeswax solutions. J. Clin. Endocrinol. Metab. 9: 268-274.

10. Bradbury, J. T., and IV. E. Brown. 1948. Absorption and excretion of chorionic gonadotropin administered intramuscularly in women. J. Clin. Endocrinol. Metab. 8: 1037-1042.

11. Franchimont, P., and A. Reuter. 1972. Evidence of $\alpha$ - and $\beta$-subunits of hCG in serum and urines of pregnant women. In Structure-Activity Relationships of Protein and Polypeptide Hormones. M. Margoulies and F. C. Greenwood, editors. Excerpta Medica, Amsterdam, The Netherlands. 381-387.

12. Hagen, C., and A. S. McNeilly. 1975. The gonadotropic hormones and their subunits in human maternal and fetal circulation at delivery. Am. J. Obstet. Gynecol. 121: 926-9.30.

13. Vaitukaitis, J. L. 1974. Changing placental concentrations of human chorionic gonadotropin and its subunits during gestation.J. Clin. Endocrinol. Metab. 38: 755-760.

14. Good, A., M. Ramos-Uribe, R. J. Ryan, and R. D. Kempers. 1977. Molecular forms of human chorionic gonadotropin in serum, urine, and placental extracts. Fertil. Steril. 28: 846-850.

15. Vaitukaitis, J. L. 1973. Immunologic and physical characterization of human chorionic gonadotropin (hCG) secreted by tumors. J. Clin. Endocrinol. Metab. 37: 505-514.

16. Canfield, R. E., and G. T. Ross. 1976. A new reference preparation of human chorionic gonadotrophin and its subunits. Bull. W. H. O. 54: 463-472. 
17. Vaitukaitis, J. L., G. D. Braunstein, and G. T. Ross. 1972. A radioimmunoassay which specifically measures human chorionic gonadotropin in the presence of human luteinizing hormone. Am. J. Obstet. Gynecol. 113: 751-758.

18. Chen, H-C., G. D. Hodgen, S. Matsuura, L. J. Lin, E. Gross, L. E. Reichert, Jr., S. Birken, R. E. Canfield, and G. T. Ross. 1976. Evidence for a gonadotropin from nonpregnant subjects that has physical, immunological, and biological similarities to human chorionic gonadotropin. Proc. Natl. Acad. Sci. U. S. A. 73: 28852889.

19. Greenwood, F. C., W. M. Hunter, and J. S. Glover. 1963. The preparation of ${ }^{131}$ I-labeled growth hormone of high specific activity. Biochem. J. 89: 114-123.

20. Rodbard, D. 1974. Statistical quality control and routine data processing for radioimmunoassays and immunoradiometric assays. Clin. Chem. 20: 1255-1270.

21. Nisula, B. C., A. R. Ayala, M. D. Stolk, G. S. Taliadouros, and J. M. Stolk. 1978. Solid-phase group-specific adsorbants in assays for glycoproteins. In Radioimmunoassay and Related Procedures in Medicine. International Atomic Energy Agency. Vienna, Austria. I: 133-140.

22. Wehmann, R. E., and B. C. Nisula. 1980. Renal clearance rates of the subunits of human chorionic gonadotropin in man. J. Clin. Endocrinol. Metab. 50: 674-679.

23. Faden, V. B., and D. Rodbard. 1975. Operating Instructions and Listings for New FORTRAN IV-G Program, EXPFIT, Exponential Data Processing. NICHD. National Institutes of Health. Bethesda.

24. Du Bois, D., and E. F. Du Bois. 1916. A formula to estimate the approximate surface area if height and weight be known. Arch. Intern. Med. 17: 863-871.

25. Snedecor, G. W., and W. G. Cochran. 1967. Statistical Methods. Iowa State University Press, Ames, Iowa.

26. Wehmann, R. E., and B. C. Nisula. 1980. Characterization of a discrete degradation product of the human chorionic gonadotropin $\beta$-subunit in humans. J. Clin. Endocrinol. Metab. 51: 101-105.
27. Braunstein, G. D., J. L. Vaitukaitis, and G. T. Ross. 1972. The in vivo behavior of human chorionic gonadotropin after dissociation into subunits. Endocrinology. 91: 10301036.

28. Wehmann, R. E., and B. C. Nisula. 1979. Metabolic clearance rates of the subunits of human chorionic gonadotropin in man. J. Clin. Endocrinol. Metab. 48: 753-759.

29. Marshall, J. C., D. C. Anderson, T. R. Fraser, and P. Harsoulis. 1973. Human luteinizing hormone in man: studies of metabolism and biological action.J. Endocrinol. 56: 431-439.

30. Schalch, D. S., A. F. Parlow, R. C. Boon, S. Reichlin, and L. A. Lee. 1968. Measurement of human luteinizing hormone in plasma by radioimmunoassay. J. Clin. Invest. 47: 665-678.

31. Kohler, P. O., G. T. Ross, and W. D. Odell. 1968. Metabolic clearance and production rates of human luteinizing hormone in pre- and postmenopausal women. J. Clin. Invest. 47: 38-47.

32. Morgan, F. J., S. Birken, and R. E. Canfield. 1975. The amino acid sequence of human chorionic gonadotropin; the $\alpha$ subunit and the $\beta$ subunit. J. Biol. Chem. 250: 5247-5258.

33. Pepperell, R. J., D. M. deKretser, and H. G. Burger. 1975. Studies on the metabolic clearance rate and production rate of human luteinizing hormone and on the initial half-time of its subunits in man.J. Clin. Invest. 56: 118-126.

34. Coble, Y. D., Jr., P. O. Kohler, C. M. Cargille, and G. T. Ross. 1969. Production rates and metabolic clearance rates of human follicle-stimulating hormone in premenopausal and postmenopausal women. J. Clin. Invest. 48: 359-363.

35. Ridgway, E. C., B. D. Weintraub, and F. Maloof. 1974. Metabolic clearance and production rates of human thyrotropin. J. Clin. Invest. 53: 895-903. 